\title{
Effects of Scarification and Stratification on Breaking Dormancy of Okra (Abelmoschus esculentus L.)
}

\author{
Vishal S. Khatik*, Bineeta M. Bara and A.K. Chaurasia \\ Department of Genetics and Plant Breeding, Naini Agricultural Institute, \\ Sam Higginbottom University of Agriculture, Technology \& Sciences Allahabad (U.P.), India
}

Corresponding author

\begin{tabular}{|c|c|}
\hline & A B S T R A C T \\
\hline $\begin{array}{l}\text { K e y w o r d s } \\
\text { Okra, } \mathrm{H}_{2} \mathrm{SO}_{4}, \\
\text { Hot water, } \\
\text { Thermometer }\end{array}$ & \multirow{3}{*}{$\begin{array}{l}\text { The laboratory experiments conducted were to study effects of scarification and } \\
\text { stratification on breaking dormancy of okra (Abelmoschus esculentus L.). during kharif } \\
\text { season 2017-18. At the seed testing laboratory, Department of Genetics and Plant } \\
\text { Breeding, Naini Agricultural Institute SHUATS, Allahabad, (UP). The design applied } \\
\text { statistical analysis was carried out with Complete Randomized Design (CRD) with } 9 \\
\text { treatments and } 4 \text { replication. The study show that seed treatment with, } \mathrm{H}_{2} \mathrm{SO}_{4} \mathrm{Scarification} \\
3 \text { min. for } 80 \% \text { (T9) recorded higher and followed by Hot water stratification } 12 \mathrm{hr} \text { for } \\
35^{\circ} \mathrm{C} \text { germination percent, speed of germination, shoot length, root length, seedling fresh } \\
\text { and dry weight, vigour index I and II, it was the best treatment. }\end{array}$} \\
\hline Article Info & \\
\hline $\begin{array}{l}\text { Accepted: } \\
\text { 10 June } 2018 \\
\text { Available Online: } \\
10 \text { July } 2018\end{array}$ & \\
\hline
\end{tabular}

\section{Introduction}

Okra (Abelmoschus esculentus $(\mathrm{L})$, also known as lady's finger or bhendi, is one of the most important vegetable crops of the tropical and subtropical regions of the world. It belongs to the genus Abelmoschus and family Malvacceae. The genus Abelmoschus is of Asiatic origin. Okra is an often cross pollinated crop having chromosome number $2 n=130$. Okra is an erect herbaceious annual having 1 to 2 meter tall. Stem is green or purple reddish tinge (Musara et al., 2015)

Endogenous dormancy is imposed by embryo or other inhibitor components inside the seed while exogenous dormancy is attributed to the seed coat. Seed coverings that impose exogenous dormancy are the endosperm, perisperm, seed coat integuments, or fruit pericarp (Geneve et al., 1998). The most common form of exogenous dormancy occurs when seed coats become suberized and impermeable to water, which is commonly known as hardseededness and is typical of many species from families such as Fabaceae, Malvaceae, Chenopodiaceae and Liliaceae (Copeland and McDonald, 2001).

Seed dormancy is a temporary failure or block of a viable seed to complete germination under physical conditions that normally favour 
(Baskin and Baskin, 2004). Two major forms of physiological seed dormancy have been described, namely embryo and coat dormancy (sometimes termed coat-enhanced dormancy). Germination commences with the uptake of water by imbibition of the dry seed, followed by embryo expansion.

Okra (Abelmoschus esculentus L.) plants exhibit seed hardness that complicates their management. Seed hardness interferes with seed germination, weed control, harvesting and other management factors (Mohammadi et al., 2011). Tough seed coats may regulate germination by establishing a permeability barrier that can interfere with the water uptake required for imbibition and subsequent radicle emergence; for gaseous exchange, particularly oxygen uptake required for respiration; and/or for the outward diffusion of endogenous germination inhibitors. Typical characteristics of hard seeds are seed coats having permeability to water but not to gases or vice versa (Budy et al., 1986).

Hardseededness can vary in a population of seeds. It is increased by environmental (dry) conditions during seed maturation, and seed storage (Baskin and Baskin, 1998). It is reported that thick walls in some okra seeds delay germination; the seeds coats are often hard and the embryo can be slow to develop during germination. Consequently, treatments to seed coats which overcome hardseededness are generally required for germination (Balla et al., 2011). The hard seed coat is of major importance for okra seed dormancy (Egley and Elmore, 1987).

The occurrence of hardseedness and the low percentage of seed germination are major challenges in growing okra. The percentage of seed germination of okra is frequently low, due to tegument impermeability and is the major barrier to the emergence of okra seeds for commercial producers . The percentage of hardseedness varies among the cultivars with some cultivars not having hardseedness or having a low percentage of hard seeds that doesn't impose any impedance on their germination, whereas for other cultivars the high percentage of hard seeds does not allow them to germinate, or allows only for low germination percentage ( Balla et al., 2011).

\section{Objectives}

1. To determine the effect of scarification and stratificationon seed germination and Vigour of Okra.

2. Investigate effective method for overcoming okra seed dormancy.

\section{Materials and Methods}

The experiment was conducted during kharif season 2017-18. At the seed testing laboratory, Department of Genetics and Plant Breeding, Naini Agriculture Institute SHUATS, Allahabad, (UP). The design applied statistical analysis was carried out with Complete Randomized Design (CRD) with 9 treatments and 4 replication. The two freshly harvested varieties are used in seed testing laboratory experiment. Seed viability test (Tz Test), $\mathrm{T}_{0^{-}}$ Control, $\mathrm{T}_{1}-$ Hot water stratification $12 \mathrm{~h}$ for $25^{\circ} \mathrm{C}, \mathrm{T}_{2^{-}}$Hot water $12 \mathrm{~h}$ for $30^{\circ} \mathrm{C}, \mathrm{T}_{3}-$ Hot water $12 \mathrm{~h}$ for $35^{\circ} \mathrm{C}, \mathrm{T}_{4}$ - Dry heat $3 \mathrm{~min}$ for $60^{\circ} \mathrm{C}, \mathrm{T}_{5}$ - Dry heat $3 \mathrm{~min}$ for $70^{\circ} \mathrm{C}, \mathrm{T}_{6}$-Dry heat $3 \mathrm{~min}$ for $80^{\circ} \mathrm{C}, \mathrm{T}_{7}-\mathrm{H}_{2} \mathrm{SO}_{4}$ Scarification @ $60 \%$ for $3 \mathrm{~min}, \mathrm{~T}_{8}-\mathrm{H}_{2} \mathrm{SO}_{4}$ Scarification@ $70 \%$ for 3 min, $\mathrm{T}_{9}-\mathrm{H}_{2} \mathrm{SO}_{4}$ Scarification@ $80 \%$ for $3 \mathrm{~min}$. The experiment was carried by during 21 DAS in used in seed testing laboratory experiment.

\section{Results and Discussion}

The result given shown in the table 1 indicate the same important parameter viz. Germination, Speed of Germination (\%), Root 
Length $(\mathrm{cm})$, Shoot Length (\%), Seedling Length(\%), Fresh Weight(g), Dry Weight(g), Vigour Index I, Vigour Index II. In case of two varieties MAHY 64 and Akra Anamika, is compared to other treatment soaking the seeds in (T9) $\mathrm{H}_{2} \mathrm{SO}_{4} @ 80 \%$ for 3 min result highest significant. These findings are similar to those by Pahla et al., (2014) who observed that $\mathrm{H}_{2} \mathrm{SO}_{4}$ promoted highest germination in Acaciaangustissima. Germination increased with the duration of exposure to $\mathrm{H}_{2} \mathrm{SO}_{4}$. As also the case with hot water treatments, it seems the length of time that seeds need to be soaked in $\mathrm{H}_{2} \mathrm{SO}_{4}$ depends on the hardness of the seed (Velempini et al., 2003). The effectiveness of $\mathrm{H}_{2} \mathrm{SO}_{4}$ concentration of $80 \%$ could be attributed to successful removal of several lignified layers in the testae, which are packed tightly together and contain water repelling compounds (Baskin, 2003). These layers act as a mechanical (physical) barrier to water absorption and gaseous exchange (Colling, 2009). This improved the germination capacity of the seeds and the time of $3 \mathrm{~min}$, probably, made sure that no other seed structure was damaged by over exposure. Scarification using acid may also enhance germination capacity by increasing the leaching of growth inhibitors from the seed (Table and

Table.1 Analysis of variance for seedling characteristics of okra

\begin{tabular}{|c|c|c|c|c|c|}
\hline \multirow{3}{*}{ S.No. } & \multirow{3}{*}{ Characters } & \multicolumn{4}{|c|}{ Mean sum of squares } \\
\hline & & \multicolumn{2}{|c|}{ Treatments $(\mathrm{df}=9)$} & \multicolumn{2}{|c|}{ Error $(d f=36)$} \\
\hline & & V1 & V2 & V1 & V2 \\
\hline 1 & $\begin{array}{l}\text { Germination } \\
\text { Percentage }\end{array}$ & $400.67 * *$ & $405.04 * *$ & 0.98 & 1.05 \\
\hline 2 & $\begin{array}{l}\text { Speed of } \\
\text { Germination }\end{array}$ & $8.63 * *$ & $8.17 * *$ & 0.01 & 0.03 \\
\hline 3 & Root length & $1.59 * *$ & $1.66 * *$ & 0.27 & 0.13 \\
\hline 4. & Shoot length & $3.03 * *$ & $3.51 * *$ & 0.39 & 0.23 \\
\hline 5 & Seedling length & $6.61 * *$ & $8.12 * *$ & 0.30 & 0.43 \\
\hline 6. & Fresh weight & $0.14 * *$ & $0.47 * *$ & 0.02 & 0.05 \\
\hline 7 & Dry weight & $0.014 * *$ & $0.019 * *$ & 7.41 & 7.66 \\
\hline 8 & Vigour index I & $297920.11 * *$ & $306137.13 * *$ & 1691.32 & 2341.16 \\
\hline 9 & Vigour index II & $220.13 * *$ & $199.33 * *$ & 0.52 & 0.46 \\
\hline
\end{tabular}


Table.2 Mean comparison of germination and vigor traits in okra

\begin{tabular}{|c|c|c|c|c|c|c|c|c|c|c|c|c|c|c|c|c|c|c|}
\hline \multirow[t]{2}{*}{ Treatment } & \multicolumn{2}{|c|}{$\begin{array}{l}\text { Germination } \\
(\%)\end{array}$} & \multicolumn{2}{|c|}{$\begin{array}{c}\text { Speed of } \\
\text { Germination } \\
(\%)\end{array}$} & \multicolumn{2}{|c|}{$\begin{array}{c}\text { Root } \\
\text { Length }(\mathrm{cm})\end{array}$} & \multicolumn{2}{|c|}{$\begin{array}{c}\text { Shoot } \\
\text { Length }(\%)\end{array}$} & \multicolumn{2}{|c|}{$\begin{array}{c}\text { Seedling } \\
\text { Length }(\%)\end{array}$} & \multicolumn{2}{|c|}{$\begin{array}{c}\text { Fresh } \\
\text { Weight (g) }\end{array}$} & \multicolumn{2}{|c|}{$\begin{array}{c}\text { Dry } \\
\text { Weight }(\mathbf{c m})\end{array}$} & \multicolumn{2}{|c|}{$\begin{array}{l}\text { Vigor } \\
\text { Index I }\end{array}$} & \multicolumn{2}{|c|}{$\begin{array}{c}\text { Vigor } \\
\text { Index II }\end{array}$} \\
\hline & $\mathrm{V}_{1}$ & $\mathrm{~V}_{2}$ & $\mathrm{~V}_{1}$ & $\mathrm{~V}_{2}$ & $\mathrm{~V}_{1}$ & $\mathrm{~V}_{2}$ & $\mathrm{~V}_{1}$ & $\mathrm{~V}_{2}$ & $\mathrm{~V}_{1}$ & $\mathrm{~V}_{2}$ & $\mathrm{~V}_{1}$ & $\mathrm{~V}_{2}$ & $\mathrm{~V}_{1}$ & $\mathrm{~V}_{2}$ & $\mathrm{~V}_{1}$ & $\mathrm{~V}_{2}$ & $\mathrm{~V}_{1}$ & $\mathrm{~V}_{2}$ \\
\hline T0 & 52.00 & 49.25 & 3.42 & 3.21 & 7.41 & 6.65 & 10.33 & 9.74 & 17.68 & 16.59 & 4.04 & 3.26 & 0.24 & 0.23 & 919.05 & 817.11 & 12.09 & 11.33 \\
\hline T1 & 67.50 & 64.75 & 6.76 & 6.58 & 8.77 & 8.73 & 2.92 & 1.98 & 1.15 & 0.68 & 4.49 & 4.23 & 0.35 & 0.33 & 1426.81 & 1328.57 & 22.94 & 21.37 \\
\hline $\mathbf{T} 2$ & 73.25 & 72.00 & 7.25 & 6.94 & 8.80 & 8.41 & 13.01 & 2.64 & 21.93 & 20.75 & 4.61 & 4.32 & 0.385 & 0.365 & 1617.44 & 1481.12 & 27.83 & 25.47 \\
\hline T3 & 80.00 & 77.00 & 7.65 & 7.24 & 9.20 & 8.47 & 13.30 & 12.70 & 21.94 & 21.51 & 4.64 & 4.35 & 0.40 & 0.385 & 1755.38 & 1656.63 & 31.81 & 29.16 \\
\hline T4 & 59.00 & 58.75 & 5.06 & 4.92 & 8.36 & 8.23 & 2.36 & 2.09 & 21.44 & 0.63 & 4.53 & 4.29 & .295 & .275 & 1204.95 & 1212.34 & 17.11 & 15.72 \\
\hline T5 & 66.50 & 64.75 & 5.57 & 5.25 & 8.57 & 7.68 & 12.24 & 11.06 & 20.76 & 19.63 & 4.54 & 4.18 & 0.33 & 0.32 & 1380.38 & 1269.94 & 21.95 & 20.92 \\
\hline T6 & 71.00 & 71.25 & 6.64 & 6.25 & 8.50 & 8.22 & 12.95 & 12.50 & 21.92 & 20.58 & 4.59 & 4.29 & 0.36 & 0.345 & 1556.97 & 1478.30 & 25.54 & 24.41 \\
\hline T7 & 9.50 & 58.00 & 5.04 & 4.92 & 8.35 & 7.75 & 12.81 & 12.18 & 21.16 & 19.74 & 4.25 & 3.89 & 0.30 & 0.29 & 1258.91 & 1144.87 & 17.75 & 16.82 \\
\hline T8 & 62.50 & 61.50 & 5.37 & 4.98 & 8.43 & 7.74 & 12.80 & 12.34 & 21.15 & 20.72 & 4.49 & 4.01 & 0.315 & 0.30 & 1318.92 & 1273.79 & 19.38 & 19.06 \\
\hline T9 & 84.75 & 83.50 & 8.29 & 8.03 & 9.85 & 8.85 & 13.31 & 12.79 & 22.03 & 21.57 & 4.66 & 4.40 & 0.45 & 0.43 & 1855.56 & 1801.21 & 36.91 & 35.75 \\
\hline MIN & 52.00 & 49.25 & 3.42 & 3.21 & 7.41 & 6.65 & 10.33 & 9.74 & 17.68 & 16.59 & 4.04 & 3.26 & 0.24 & 0.23 & 919.05 & 817.11 & 12.09 & 11.33 \\
\hline MAX & 84.75 & 83.50 & 8.29 & 8.03 & 9.85 & 8.85 & 13.31 & 12.79 & 22.03 & 21.57 & 4.66 & 4.40 & 0.45 & 0.43 & 1855.56 & 180 & 36.91 & 35.75 \\
\hline S Em & 0.878 & 0.692 & 0.062 & 0.027 & 0.260 & 0.184 & 0.313 & 0.243 & 0.275 & 0.330 & 0.077 & 0.116 & 0.015 & 0.010 & 26.245 & 28.423 & 1.192 & 0.770 \\
\hline CV & 1.467 & 1.557 & 2.023 & 0.914 & 4.571 & 6.035 & 4.966 & 4.046 & 2.610 & 3.264 & 3.429 & 5.613 & 4.543 & 4.967 & 2.865 & 3.594 & 3.100 & 3.088 \\
\hline CD at $5 \%$ & 2.536 & 1.999 & 0.178 & 0.077 & 0.751 & 0.533 & 0.904 & 0.701 & 0.796 & 0.954 & 0.221 & 0.334 & 0.043 & 0.030 & 75.802 & 82.122 & 3.443 & 2.225 \\
\hline
\end{tabular}


Baskin (1998) noted that the whole idea behind treating the seeds is to either completely remove the germination impeding seed coat or to reduce its thickness so that the seed could emerge. Removal or reduction in thickness of the seed coat allows the seed to take up water and respiratory gases thus the germination process can be initiated. The experiment was followed by treatment $\left(\mathrm{T}_{3}\right)$ Hot water $12 \mathrm{hr}$. for $35^{\circ} \mathrm{C}$ result significant. The soaking for $12 \mathrm{~h}$ treatment seems to have promoted the leaching of germination inhibitors on the tastae of okra seeds (Xia and Kermode, 2002). This may be attributed to water trapped in tissue between the embryo and seed coat creating an oxygen barrier (Reisman-Berman et al., 1989). Moreover, Norton (1986) concluded that anoxia caused by prolonged soaking of seeds may result in irreversible injury due to accumulation of toxic metabolites hence poor germination.

It is concluded form the present study different seed treatments showed that significant effect on seedling parameters, treated with, $\mathrm{H}_{2} \mathrm{SO}_{4}$ (Scarification) $3 \mathrm{~min}$. for $80 \%\left(\mathrm{~T}_{9}\right)$ recorded higher and followed by Hot water (stratification) $\left(\mathrm{T}_{3}\right) 12 \mathrm{hr}$ for $35^{\circ} \mathrm{C}$. germination percent, speed of germination, shoot length, root length, seedling fresh and dry weight, vigour index I and II, it was the best treatment.. Acid scarification and hot water are effective methods of breaking okra seed dormancy which can be utilised by smallholder farmers.

\section{References}

Balla, M. M. A., Saidahmed A. I. and Makkawi M. (2011).Effect of moisture content and maturity on hardseededness and germination in okra. (Abelmoschus esculentus L. Moench) International Journal of Plant Physiology and Biochemistry. 3(6): 102-107.
Baskin CC (2003).Breaking physical dormancy in seeds - focusing on the lens.New Phytol.158:227 238

Baskin, J. M. and Baskin, C. C. (2004).A classification system for seed dormancy. Seed Science Research.14: $1-16$.

Baskin, J. M., and Baskin, C. C. (1998). Seeds: Ecology, Biogeography and Evolution of Dormancy and Germination. San Diego. Academic Press.

Budy, J., Evans, R., and Young, J. (1986).Understanding seed handling for germination. Arlington, VA: Volunteers in Technical Assistance.

Colling J. (2009). Towards understanding the metabolism of in vitro Sutherlandiafrutescens (L.) R. Br. Cultures. MSc Thesis: Stellenbosch University, South Africa. 53-66.

Copeland, L. O., and McDonald, M. B. (2001).Principles of seed science and technology. Boston. Kluwer Academic Publishers. 1: 4615-1619

Egley, G. H., and Elmore, C. D. (1987).Germination and the potential persistence of weedy and domestic okra. (Abelmoschus esculentus (L.) Moench.) seeds. Weed Science.35: 4551.

Geneve, R. L. (1998). Seed dormancy in commercial vegetable and flower species. Seed Technolgy.20: 236-250.

Mohammadi, G., Ebrahim, M. K., and Mohammad, B. A. (2011).Differential responses for harvesting times and storage on hardness of different varieties of okra. National Biological Science.3(4): 117-122.

Musara, C. (2015). Evaluation of different seed dormancy breaking techniques on Okra (Abelmoschus esculentus L.)seed germination. African Journal of Agriculture Research.10(17):19521956 
Norton, C.R. (1986). Germination under flooding: Metabolic implications and alleviation of injury. Horticulture Science. 21:1123-1125.

Reisman-Berman O., Kigel, J. and Rubin, B. (1989). Short soaking in water inhibits germination of Daturaferox and $D$. stramonium L. seeds. Weed Reserch.29:357-363.

Velempini, P., Riddoch, I., and Batisani N (2003).Seed treatments for enhancing germination of wild okra (Corchorus olitorius).Exp. Agric. 39:441-447.

Xia, J.H.and Kermode, A.R. (2002). Dormancy of yellow cedar (Chamaecyparis nootkatensis [D.Don] Spach) seed is effectively terminated by treatment with 1-propanol or nitrate in combination with warm water soaking gibberellin and moist chilling. Seed Science and Technology.28:227240.

\section{How to cite this article:}

Vishal S. Khatik, Bineeta M. Bara and Chaurasia, A.K. 2018. Effects of Scarification and Stratification on Breaking Dormancy of Okra (Abelmoschus esculentus L.). Int.J.Curr.Microbiol.App.Sci. 7(07): 1667-1672. doi: https://doi.org/10.20546/ijcmas.2018.707.196 